\title{
Is the $\mathrm{CO}_{2}$ hunter a green, black or white mineral?
}

\author{
EMILY TE PAS, MATHILDE HAGENS AND ROB \\ COMANS
}

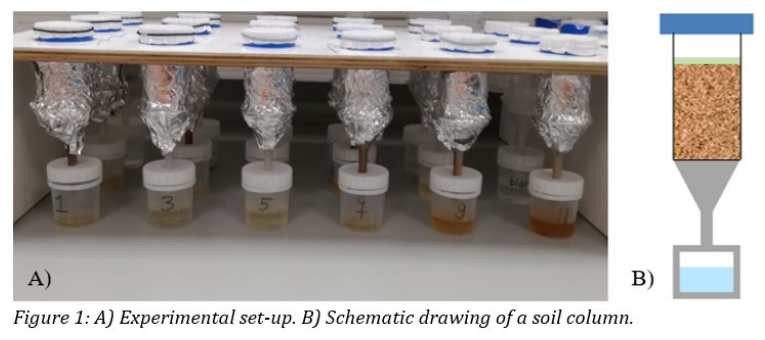

Wageningen University \& Research

Presenting Author: emily.tepas@wur.nl

Enhanced weathering involves the spreading of crushed silicate minerals aimed at long-term carbon dioxide $\left(\mathrm{CO}_{2}\right)$ sequestration. This negative emission technology may co-benefit agricultural productivity by increasing soil $\mathrm{pH}$ and releasing nutrients. Silicate minerals and rocks differ in their enhanced weathering potential, i.e. their potential for $\mathrm{CO}_{2}$ sequestration and soil quality improvements. However, studies comparing minerals for this dual potential are lacking. Therefore, we quantified and compared the enhanced weathering potential for the increasingly studied olivine, basalt, and wollastonite, and two minerals that have not been investigated in this context yet, anorthite and albite. A down-flow soil column experiment was specifically designed for soil and leachate analyses (Figure 1). Each silicate was applied on a bare sandy soil (125 $\mathrm{g} \mathrm{kg}^{-1}$ soil). Water additions every two to four days resulted in outflow of leachate, in which $\mathrm{pH}$, alkalinity, dissolved organic and inorganic carbon, base cations, and nickel $(\mathrm{Ni})$ concentrations were measured. After two months, soils were also analysed for these parameters.

Depending on the calculation method, highest $\mathrm{CO}_{2}$ capture was measured for albite weathering $\left(3.69 \mathrm{~g} \mathrm{CO}_{2} \mathrm{~kg}^{-1}\right.$ soil, using magnesium mass balances) or olivine weathering (1.39 $\mathrm{g} \mathrm{CO}_{2}$ $\mathrm{kg}^{-1}$ soil, using alkalinity and carbonate measurements). Furthermore, high $\mathrm{CO}_{2}$ sequestration was shown for wollastonite and anorthite weathering, when expressed as $\mathrm{CO}_{2}$ capture per mineral reactive surface area. However, full carbon budgets indicated net $\mathrm{CO}_{2}$ emissions from basalt amended soils. All treatments increased soil $\mathrm{pH}$ and base saturation, with the highest responses for olivine and wollastonite. Soil $\mathrm{Ni}$ concentrations remained within micronutrient levels, while wollastonite and especially olivine weathering induced $\mathrm{Ni}^{2+}$ leachate concentrations exceeding groundwater quality thresholds, thereby reducing the enhanced weathering potential of both minerals.

Our results showed a high enhanced weathering potential for albite and olivine weathering, while wollastonite and anorthite weathering require further research. This study highlights the importance of measuring I) both organic and inorganic carbon budgets to assess net $\mathrm{CO}_{2}$ sequestration, and II) Ni leaching from soils to monitor possible adverse side effects. We conclude that enhanced weathering using albite and olivine, and potentially anorthite and wollastonite, is promising for the transition towards net negative emissions. 